Article

\title{
Investigation of Aerosol Climatology, Optical Characteristics and Variability over Egypt Based on Satellite Observations and In-Situ Measurements
}

\author{
Islam Abou El-Magd ${ }^{1, *(D)}$, Naglaa Zanaty ${ }^{1}$, Elham M. Ali ${ }^{2}$, Hitoshi Irie ${ }^{3}$ and \\ Ahmed I. Abdelkader 4 \\ 1 National Authority for Remote Sensing and Space Sciences (NARSS), Cairo 1564, Egypt; \\ Naglaa.zanaty@narss.sci.eg \\ 2 Faculty of Fish Resources, Suez University, Suez 41522, Egypt; elhamali@narss.sci.eg \\ 3 Center for Environmental Remote Sensing, Chiba University, 1-33 Yayoi-cho, Inage-ku, \\ Chiba-shi 263-8522, Japan; hitoshi.irie@chiba-u.jp \\ 4 Faculty of Science, Port Said University, Port Said 42511, Egypt; ahmed.ismail@sci.psu.edu.eg \\ * Correspondence: imagd@narss.sci.eg
}

Received: 23 April 2020; Accepted: 23 June 2020; Published: 3 July 2020

\begin{abstract}
Egypt experiences high rates of air pollution, which is a major threat to human health and the eco-environment and therefore needs to be tackled by defining major causes to hinder or mitigate their impacts. The major driving forces of air pollution are either of local and/or regional origin. In addition, seasonal aerosols may be natural, such as dust particles transported from the western desert, or anthropogenic aerosols which are transported from industrial areas and smoke particles from seasonal biomass burning. Monitoring the optical properties of aerosols and their pattern in the atmosphere on a daily basis requires a robust source of information and professional analytical tools. This research explored the potential of using time series of Moderate Resolution Imaging Spectroradiometer (MODIS) and Aerosol Robotic Network (AERONET) data to comprehensively investigate the aerosol optical depth (AOD) and variability for the period 2012-2018 on a daily basis. The data show that spring, summer and autumn seasons experienced the highest anomaly originating from regional and national sources. The high AOD in spring associated with a low Angström exponent $(\mathrm{AE})$ indicates the presence of coarse particles which naturally originate from desert dust or sea spray. In contrast, the high $\mathrm{AE}$ in summer and autumn demonstrated the dominance of fine anthropogenic aerosols such as smoke particles from local biomass burning. The observation of a high number of fire incidents over Egypt in October and November 2018, during the months of rice crop harvesting, showed that these incidents contribute to the presence of autumn aerosols across the country. In-situ measurements of Particulate Matter $\left(\mathrm{PM}_{10}\right)$ from local stations from an environmental based network as well as the AERONET AOD were used to validate the MODIS AOD, providing a high correlation coefficient of $r=0.73$.
\end{abstract}

Keywords: Egypt; aerosols; MODIS; aerosol optical depth (AOD); AERONET

\section{Introduction}

Atmospheric aerosols are small particles which are suspended in the atmosphere in a solid or liquid state. An aerosol's size varies from nanometers to tens of micrometers according to their origin, which is either natural (e.g., volcanic eruption, dust storms and sea salt) or from human activities (e.g., biomass burning) [1]. Aerosols can alter the radiation balance of the earth by scattering or absorption [2] and contribute to visibility reduction [3]. The physical and optical characteristics of aerosols such as the aerosol optical depth (AOD), aerosol size distribution and single scattering 
albedo (SSA) can control the radiative forcing of aerosols at the surface and top of the atmosphere [4]. These properties vary with space, time and other factors including the mixing state and processes such as coagulation, gas-to-particle conversion and hydration, which influence the particle size and concentration. The aerosol loading can be reduced due to the effect of gravitational settling and washout through precipitation and scavenging [1]. Thus, the investigation of AOD and aerosol size distribution is important to understand an aerosol's type and origin [5]. The Ångström exponent (AE) can explain the dependence of AOD on wavelength and provide basic information on aerosol size distribution, such as the presence or absence of large particles (e.g., dust) [2,4].

Huge amounts of dust are emitted every year from arid-semiarid areas and are transported up to several thousands of kilometers by winds [6]. North Africa is considered one of the greatest dust-producing regions in the world $[7,8]$. The Sahara and Sahel contribute to $50-70 \%$ of the global mineral dust budget $[9,10]$. Air masses loaded with dust are transported over a large distance to remote areas across the Atlantic Ocean to the Americas and eastward towards the Middle East and Europe [11]. Several thousands of tons of dust from the Sahara affect the European environmental systems [12]. During heavy dust outbreaks, the dust levels of Southern European countries (e.g., Greece, Italy and Spain) often exceed the European Union standards [13-15]. In addition, dust can be detected in Europe's high-latitude areas such as in the British Isles, Germany and Central Europe (the Carpathian Basin) e.g., $[12,16,17]$.

Aerosol properties can be examined at ground-based stations by in-situ and remote measurements (e.g., Aerosol Robotic Network-AERONET) [18] and by satellite instruments such as the Multiangle Imaging Spectroradiometer (MISR) and Moderate Resolution Imaging Spectroradiometer (MODIS) [19]. Remote sensing techniques applied to retrieve aerosol loading and characterizations provide strong observational constraints on model depictions of global aerosol distribution. Although other observation types provide important information and help to constrain models, only satellite remote sensing has the ability to observe and quantify aerosol properties globally $[20,21]$. Aerosol optical depth is an indicator of the aerosol loading in the atmosphere and constitutes the main parameter used to assess aerosol radiative forcing and its effects on climate [4,22]. AOD represents the degree to which aerosols affect the scattering and absorption of light in the atmosphere; it depends on aerosol properties (e.g., size, mass) and sources and determines their effect on the Earth's radiation balance [22,23].

Satellite remote sensing sensors such as MODIS derive aerosol products from the measured spectral radiances [20]. MODIS provides daily observations of global AOD over the land and ocean using different independent algorithms. The Dark Target (DT) algorithm $[24,25]$ retrieves the AOD over vegetation and the ocean, as well as over dark areas of the Earth. In contrast, the Deep Blue (DB) algorithm [26-28] retrieves the AOD over bright land surfaces (e.g., desert) at different visible light wavelengths.

Various studies have used satellite data to observe atmospheric aerosol characteristics worldwide [4,20,21,29-34]. In Egypt, research studies have been carried out on atmospheric aerosols with a particular focus on Cairo and the Nile delta region [33,35-42] due to their high pollution load. Shokr [36] discussed aerosol characteristics over five Egyptian cities using MODIS Aqua aerosol data. The study revealed that the highest AOD values were over Cairo, Alexandria, and the Nile delta region. In another study conducted by El-Askary et al. [37], one of the highly influencing events on aerosol loading over the Nile delta, namely the "black cloud" phenomenon, was investigated. Black cloud is a phenomenon due to the dense black smoke that covers Cairo and the Nile delta in the autumn season (October and November) and is attributed to the burning by farmers of rice straw after harvesting. The study showed that a huge number of aerosols originated from many regions in the delta and affected the surrounding areas through air mass circulation processes. The seasonal variations in AOD over Egypt were explored by El-Askary [38] over Cairo and the delta using MODIS data from 2000 to 2005. The data showed that high values of AOD were found during spring and autumn months, at the time of the occurrence of dust storms (April and May) and black cloud formation (September and October). Li et al. [33] confirmed the impact of dust storms on seasonal aerosol loading, 
with summer and spring being affected by dust storms originating from the Saharan desert, while autumn is affected by biomass burning together with desert dust forming a large column loading of aerosols. In addition, in a study conducted by El-Metwally et al. [35] on the impacts of aerosols on solar radiation transfer using AERONET data, it was concluded that the three dominant aerosol components in Egypt are (1) the highly absorbing aerosols produced by daily activities, (2) aerosols produced from burning agricultural wastes in the Nile delta region and (3) desert dust. Each of these aerosol components combine with human activities and lead to the occurrence of heat islands over Cairo, Abou, El-Magd, et al. [39].

The purpose of this research is to intensively examine for the first time the temporal and spatial variations of atmospheric aerosols over Egypt from 2012 to 2018 using both MODIS Terra and AERONET data. The goal is to investigate the aerosol climatology and the optical characteristics over the region in order to understand the main driving forces that influence the aerosol loading around the year; to provide a better and complete understanding of the causes, impacts and methods of migration; and to compare the seasonal variations in AOD and detect the sources that influence the aerosol loading.

\section{Study Area, Materials and Methods}

\subsection{Study Area Description}

Geographically, Egypt is enclosed by two desert plateaus from both eastern and western sides and the Mediterranean Sea to the North (Figure 1). Because of the geographic location of Egypt, as well as due to industrialization and over-population, there are many contributors to the increase in pollution levels. During the windy season (e.g., spring), the accelerated dust moves from the desert towards the Nile valley and Cairo and leads to increasing levels of pollution [40]. Intensive population growth is an additional source of local emissions (e.g., transportation and biomass burning). A recent population estimate for 2019 by the Central Agency for Public Mobilization and Statistics (CAPMAS) exceeded 102 million recorded censuses [43]. Commonly, the prevalent types of aerosols over Egypt can be defined as (1) dust blown from the desert, (2) sea salt over the Mediterranean Sea, (3) biomass burning in the Nile delta and (4) local activities from industrial and urbanized areas [36].

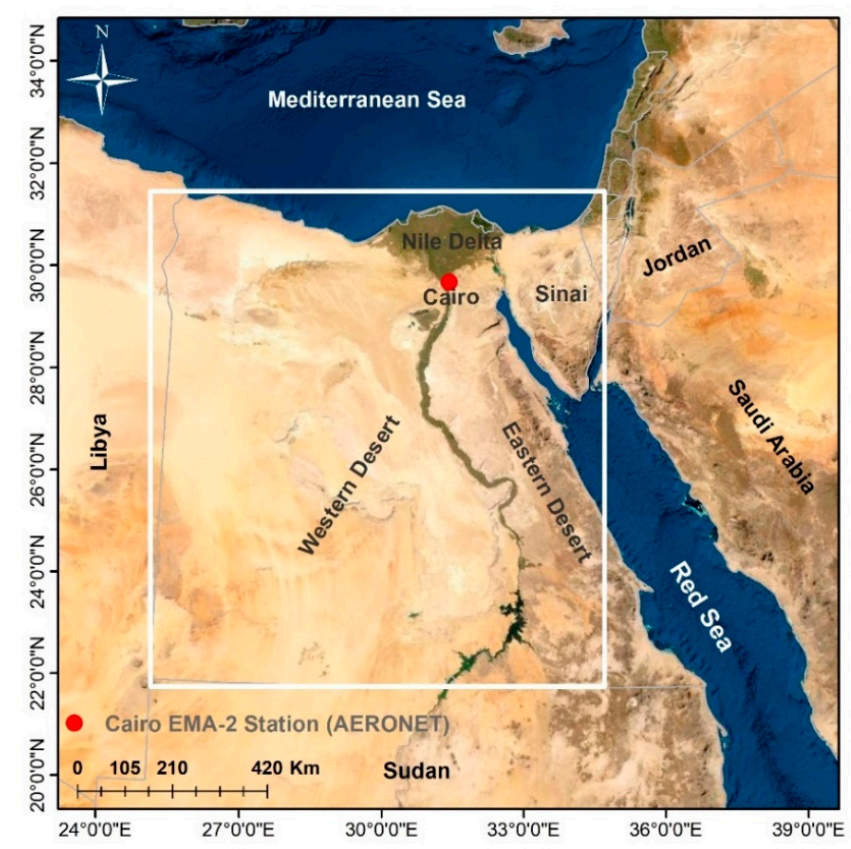

Figure 1. Location map of Egypt; the white box represents the domain $\left(25^{\circ} 2^{\prime} 36^{\prime \prime} \mathrm{E}, 21^{\circ} 49^{\prime} 50^{\prime \prime} \mathrm{N}\right.$ \& $34^{\circ} 54^{\prime} 39^{\prime \prime} \mathrm{E}, 31^{\circ} 52^{\prime} 46^{\prime \prime} \mathrm{N}$ ) selected for data analysis, and the red point shows the Cairo Egyptian Meteorological Authority (EMA-2) Aerosol Robotic Network (AERONET) station. 
Egypt has become one of the most highly polluted countries in the world. As estimated by the World Health Organization (WHO), urban areas in Egypt experienced an annual mean concentration of fine particulate matter $\left(\mathrm{PM}_{2.5}\right)$ of about $100.6 \mu \mathrm{g} / \mathrm{m}^{3}$ in 2014 and $79.6 \mu \mathrm{g} / \mathrm{m}^{3}$ in 2016 [44,45]. This caused the negative exposure of local living inhabitants to high levels of pollution. The WHO reported that the mortality rate of 50.9 per 100,000 inhabitants that was attributed to ambient air pollution in 2012 was doubled in few years, reaching 108.9 in 2016 per 100,000 inhabitants in Egypt [44,45]. Economically, the World Bank in 1999 reported that the cost of pollution is $4.8 \%$ of gross domestic product in Egypt. Moreover, air pollution increases the number of patients with bronchial asthma and respiratory obstruction; the number of bronchial asthma patients doubles particularly at the time of air pollution episodes (autumn season) [46].

\subsection{Data Set and Analysis Methods}

In this research, satellite data from MODIS and ground-based measurements from AERONET were both used to obtain a clear picture and full understanding of the aerosol climatology over Egypt. In addition, in-situ measurements of particulate matter acquired from the environmental monitoring stations affiliated with the Egyptian Environmental Affairs Agency (EEAA) were included. Table 1 presents the characteristics of the data set used in this research study. The data include MODIS level 2 and level 3 aerosol products acquired freely from the NASA website [47] during the period from 2012 to 2018 on a daily basis. Level 2 aerosol data are the fundamental MODIS aerosol product, available in an un-gridded format with a $3 \times 3 \mathrm{~km}$ and $10 \times 10 \mathrm{~km}$ spatial resolution. Level 3 data are available in a gridded format with a spatial resolution of $1^{\circ} \times 1^{\circ}$. Daily and monthly measures of combined Deep Blue (DB) and Dark Target (DT) AOD products [48] were also used from MODIS Terra satellite data over the land and ocean. They were examined at $550 \mathrm{~nm}$ within the geographic boundaries of Egypt to explore the temporal variations in AOD during the investigation period. AOD from MODIS was analyzed at $550 \mathrm{~nm}$, which is the prevalent reference wavelength reported by satellite products. In addition, MODIS fire data acquired from [49] were used to study the impact of fire on AOD levels during the season of burning rice straw (October and November)

Table 1. Characteristics and sources of data used in this study. MODIS: Moderate Resolution Imaging Spectroradiometer; AOD: aerosol optical depth.

\begin{tabular}{|c|c|c|c|c|c|c|}
\hline Data Name & Product & Level & $\begin{array}{l}\text { Observation } \\
\text { Time }\end{array}$ & Wavelength & $\begin{array}{c}\text { Temporal } \\
\text { Resolution }\end{array}$ & $\begin{array}{c}\text { Spatial } \\
\text { Resolution }\end{array}$ \\
\hline $\begin{array}{c}\text { MODIS Terra } \\
\text { AOD (land and } \\
\text { Ocean) }\end{array}$ & MOD04 & 2 & 2012-2018 & $550 \mathrm{~nm}$ & Daily/Monthly & $10 \mathrm{~km}$ \\
\hline $\begin{array}{l}\text { MODIS Terra } \\
\text { AOD (land only) }\end{array}$ & MOD04 & 2 & 2012-2018 & $\begin{array}{l}470 \mathrm{~nm} \\
550 \mathrm{~nm} \\
660 \mathrm{~nm}\end{array}$ & Daily/Monthly & $10 \mathrm{~km}$ \\
\hline $\begin{array}{c}\text { MODIS Terra } \\
\text { combined Dark } \\
\text { Target and Deep } \\
\text { Blue algorithms }\end{array}$ & MOD08 & 3 & 2012-2018 & $550 \mathrm{~nm}$ & Daily/Monthly & $1^{\circ}$ \\
\hline AERONET AOD & $\begin{array}{c}\text { AOD } \\
500 \mathrm{~nm}\end{array}$ & 2 & 2012-2018 & $500 \mathrm{~nm}$ & Daily/Monthly & $\begin{array}{l}\text { Point } \\
\text { location }\end{array}$ \\
\hline $\begin{array}{c}\mathrm{PM}_{10} \\
\text { concentrations }\end{array}$ & In-situ & - & 2016 & - & Hourly & $\begin{array}{l}\text { Point } \\
\text { location }\end{array}$ \\
\hline
\end{tabular}

Otherwise, optical properties from AERONET including AOD and AE were investigated during the period 2012-2018. AERONET data were used to explore the climatology of AOD at $500 \mathrm{~nm}$ and AE at $440-870 \mathrm{~nm}$ in addition to validating MODIS AOD data due to their high accuracy. AERONET is a network-wide estimation method for AOD based on Sunphotometer measurements which is distributed 
all over the world. In the current analysis, quality-assured aerosol level 2.0 data were acquired on a daily basis from the AERONET station of "Cairo_EMA_2" located at 30.081 N, 31.290 E. AERONET data are available at https://aeronet.gsfc.nasa.gov/new_web/aerosols.html.

AE can be calculated using the spectral variation of AOD by applying the Volz method (Equation (1)) to distinguish the different aerosol types [4,50]:

$$
\propto=-\frac{d \ln \tau}{d \ln \lambda}=-\frac{\ln \left(\frac{\tau_{1}}{\tau_{2}}\right)}{\ln \left(\frac{\lambda_{1}}{\lambda_{2}}\right)}
$$

where $\alpha$ is the AE and $\tau_{1}$ and $\tau_{2}$ are the AOD at wavelengths of $\lambda_{1}$ and $\lambda_{2}$, respectively.

Furthermore, in-situ measurements of $\mathrm{PM}_{10}$ from the Egyptian Environmental Affairs Agency (EEAA) network stations that cover Cairo and the Nile delta were used. This data set is very useful in the validation of satellite data and provides a full understanding of the real picture of aerosols and particulate matter in the area. Table 2 shows the location of these stations and the type of area covered. In total, 5589 records of data were analyzed with about $63 \%$ observation; however, the individual station observation could be in the low range from $1 \%$ to $7 \%$ (Table 2 ). Such a low individual observation is estimated relative to the amount of measured data for the total number of hours in the year. In addition, a list of dust events in the same year recorded by the early warning department at EEAA is used as a reference to validate the AOD data.

Table 2. Characterization of the environmental monitoring stations affiliated to Egyptian Environmental Affairs Agency (EEAA) used as a reference for $\mathrm{PM}_{10}$ measurements in 2016.

\begin{tabular}{|c|c|c|c|c|c|}
\hline Station Name & Longitude & Latitude & Type & $\begin{array}{c}\text { No. of } \\
\text { Available Data } \\
\text { Points }\end{array}$ & $\begin{array}{c}\text { Mean } \text { PM }_{10} \\
\mu \mathrm{g} / \mathrm{m}^{3}\end{array}$ \\
\hline Al-Salam & $31^{\circ} 26^{\prime} 51.99^{\prime \prime} \mathrm{E}$ & $30^{\circ} 9^{\prime} 22.71^{\prime \prime} \mathrm{N}$ & Mixed & 290 & 172.7 \\
\hline Shoubra & $31^{\circ} 16^{\prime} 13.56^{\prime \prime} \mathrm{E}$ & $30^{\circ} 6^{\prime} 40.80^{\prime \prime} \mathrm{N}$ & Industrial & 581 & 163.3 \\
\hline Masr El-Gedida & $31^{\circ} 20^{\prime} 13.49^{\prime \prime} \mathrm{E}$ & $30^{\circ} 6^{\prime} 24.01^{\prime \prime} \mathrm{N}$ & Residential & 236 & 131.3 \\
\hline Nasser City & $31^{\circ} 19^{\prime} 29.79^{\prime \prime} \mathrm{E}$ & $30^{\circ} 3^{\prime} 36.39^{\prime \prime} \mathrm{N}$ & Residential & 469 & 113.8 \\
\hline Al-Qollaly & $31^{\circ} 14^{\prime} 38.00^{\prime \prime} \mathrm{E}$ & $30^{\circ} 3^{\prime} 36.98^{\prime \prime} \mathrm{N}$ & Traffic/urban & 556 & 161.4 \\
\hline Six of October & $30^{\circ} 52^{\prime} 59.37^{\prime \prime} \mathrm{E}$ & $29^{\circ} 56^{\prime} 9.32^{\prime \prime} \mathrm{N}$ & Residential/Industrial & 416 & 202.4 \\
\hline Mohandesen & $31^{\circ} 12^{\prime} 43.39^{\prime \prime} \mathrm{E}$ & $30^{\circ} 2^{\prime} 47.70^{\prime \prime} \mathrm{N}$ & Residential & 423 & 224.8 \\
\hline Helwan & $31^{\circ} 19^{\prime} 10.27^{\prime \prime} \mathrm{E}$ & $29^{\circ} 51^{\prime} 54.82^{\prime \prime} \mathrm{N}$ & Residential/Industrial & 106 & 469.6 \\
\hline Tebin & $31^{\circ} 18^{\prime} 11.10^{\prime \prime} \mathrm{E}$ & $29^{\circ} 46^{\prime} 55.04^{\prime \prime} \mathrm{N}$ & Industrial & 322 & 124.2 \\
\hline Al Maadi & $31^{\circ} 15^{\prime} 51.80^{\prime \prime} \mathrm{E}$ & $29^{\circ} 58^{\prime} 2.71^{\prime \prime} \mathrm{N}$ & Residential & 120 & 469.6 \\
\hline Al-Maasara & $31^{\circ} 12^{\prime} 42.88^{\prime \prime} \mathrm{E}$ & $30^{\circ} 0^{\prime} 34.79^{\prime \prime} \mathrm{N}$ & Mixed & 462 & 254.7 \\
\hline New Cairo & $31^{\circ} 25^{\prime} 6.93^{\prime \prime} \mathrm{E}$ & $29^{\circ} 59^{\prime} 36.39^{\prime \prime} \mathrm{N}$ & Residential & 359 & 94 \\
\hline Abbasia & $31^{\circ} 17^{\prime} 27.43^{\prime \prime} \mathrm{E}$ & $30^{\circ} 4^{\prime} 47.91^{\prime \prime} \mathrm{N}$ & Residential/urban & 240 & 138 \\
\hline Nasser Institute & $31^{\circ} 14^{\prime} 24.43^{\prime \prime} \mathrm{E}$ & $30^{\circ} 5^{\prime} 44.10^{\prime \prime} \mathrm{N}$ & Urban & 292 & 272 \\
\hline Qaha & $31^{\circ} 12^{\prime} 24.27^{\prime \prime} \mathrm{E}$ & $30^{\circ} 17^{\prime} 10.14^{\prime \prime} \mathrm{N}$ & Remote Area & 452 & 214 \\
\hline Shebin El-Kom & $31^{\circ} 0^{\prime} 35.48^{\prime \prime} \mathrm{E}$ & $30^{\circ} 33^{\prime} 25.51^{\prime \prime} \mathrm{N}$ & Urban & 169 & 313 \\
\hline $\begin{array}{c}\text { Al Mahala } \mathrm{Al} \\
\text { kobra }\end{array}$ & $31^{\circ} 0^{\prime} 58.35^{\prime \prime} \mathrm{E}$ & $30^{\circ} 46^{\prime} 31.07^{\prime \prime} \mathrm{N}$ & Industrial & 96 & 230 \\
\hline
\end{tabular}

Trajectory models are a commonly used approach to describe the paths of air parcels by calculating single mean-wind trajectories. Backward trajectories are helpful for the interpretation of local events, provide information on the main directions of air masses and identify the main emission sources 
influencing the area [51]. In this study, five-day backward trajectory analyses were calculated using the Meteorological Data Explore (METEX) trajectory model [52]. METEX was developed with an emphasis on flexibility and ease-of-use based on meteorological databases to detect the movement of air masses on a regional scale [51]. The current analyses were initialized at two locations over Egypt: (1) on 1st May 2018 at $30^{\circ} 15^{\prime} \mathrm{N} \& 31^{\circ} 10^{\prime} \mathrm{E}$ and (2) on 10th May 2018 at $27^{\circ} 14^{\prime} \mathrm{N} \& 30^{\circ} 58^{\prime}$ at $500 \mathrm{~m}$ altitude.

\section{Results}

\subsection{Variations in MODIS AOD}

The analysis of AOD changed from annual to monthly and from seasonal to daily to get a better understanding of the main driving forces of aerosol loading. There were monthly variations in AOD; the highest peak was reached at 0.67 in May 2018, with anomalies and fluctuations in each year with different peaks. The mean value of AOD (0.3) during the period of investigation plus one standard deviation (0.09) was used as a standard reference to detect high anomalies of AOD, as shown in Figure 2.

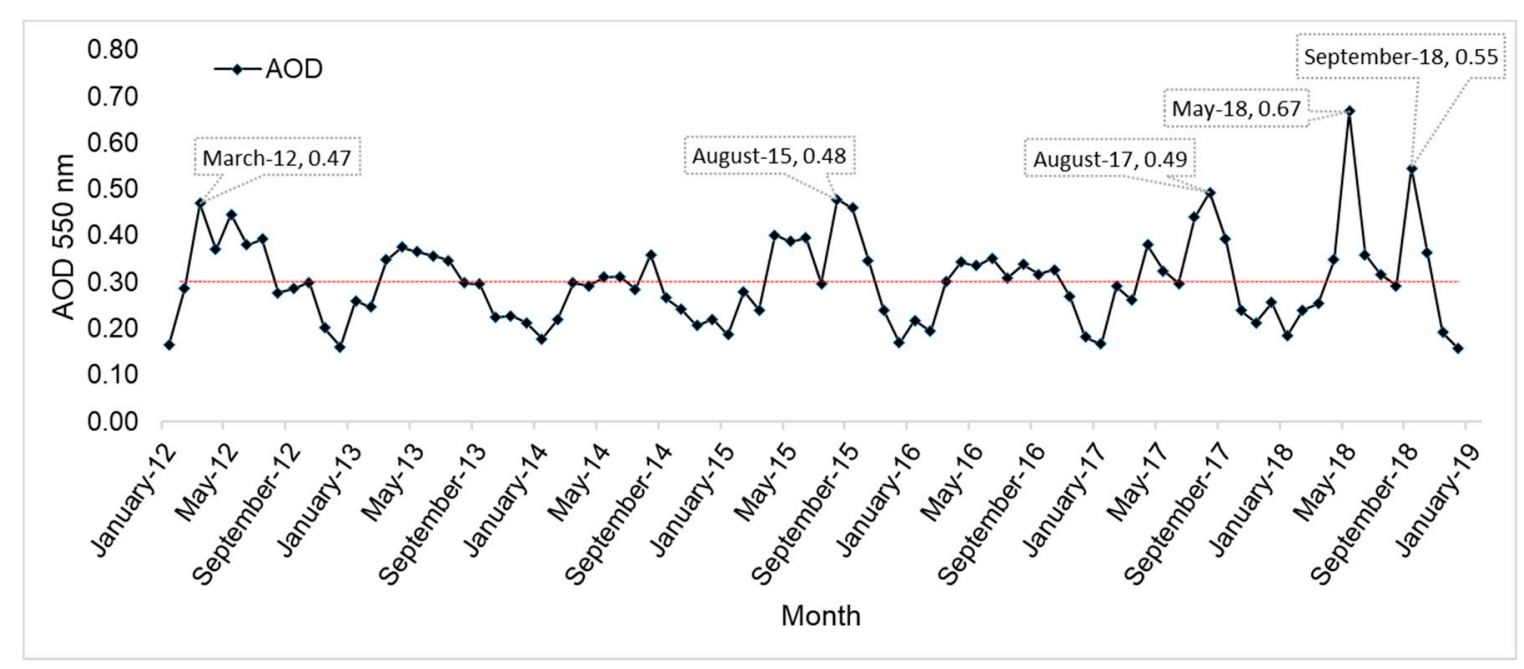

Figure 2. Time series of monthly AOD from MODIS Terra over Egypt (252 $26^{\prime \prime}$ E, $21^{\circ} 49^{\prime} 50^{\prime \prime} \mathrm{N}$ \& $\left.34^{\circ} 54^{\prime} 39^{\prime \prime} \mathrm{E}, 31^{\circ} 52^{\prime} 46^{\prime \prime} \mathrm{N}\right)$ for the period 2012 to 2018 . The red line represents the reference value of AOD (mean AOD + standard deviation).

Further analysis on a narrow time scale down to daily measurements in 2018 was carried out to investigate the high AOD recorded in this year, as shown in Figure 3. As observed from the figure, there was a large presence of aerosols found in May and October. Further analysis was carried out on AOD in May 2018 to detect the driving force of high AOD values. Based on a visual interpretation of MODIS Terra level 1 colored images on the 1st and 10th of May 2018, a dust storm occurred over Egypt. Thus, the level 3 combined DT and DB AOD at $550 \mathrm{~nm}$ was explored on the same days to show the AOD distribution aligned with the dust events, as shown in Figure 4. Dust storms are frequent in spring due to the prevalent "Khamasin" wind in this season.

In order to describe the movement of air masses and the source of the dust events recorded on the 1st and 10th of May 2018, a back-trajectory analysis was performed (Figure 5). By analyzing the five-day backward trajectory initiated on both the 1st and 10th of May, it was observed that, on the 1st of May, the air masses originated from the northern and western directions, while on the 10th of May, the air mass came from the north-western direction and circulated in the western desert for the previous 2 days. 


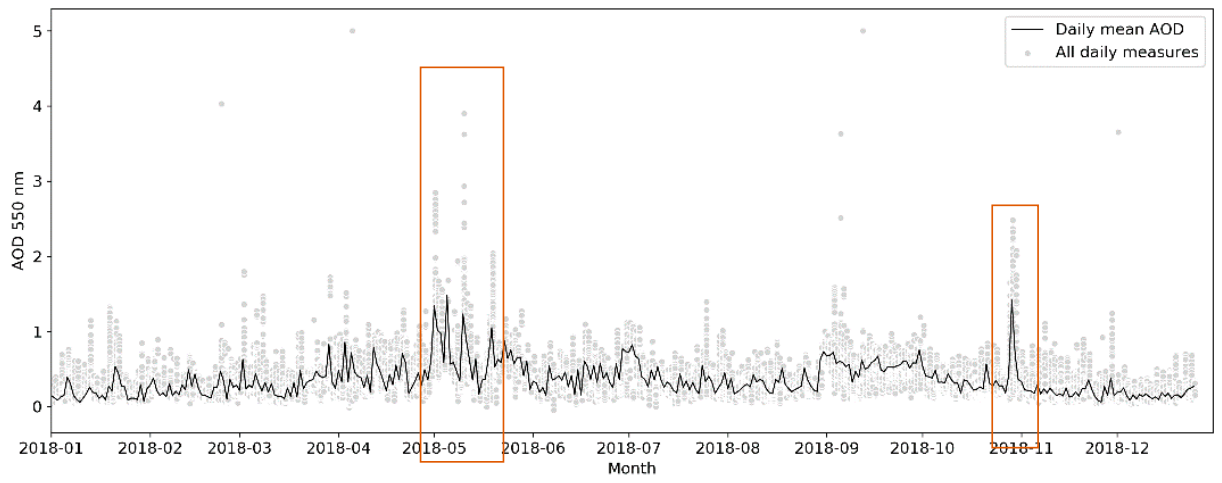

Figure 3. Temporal variations of AOD over Egypt from MODIS. The black line represents the daily mean AOD; the scattered grey points represent all daily measurements of AOD in 2018.

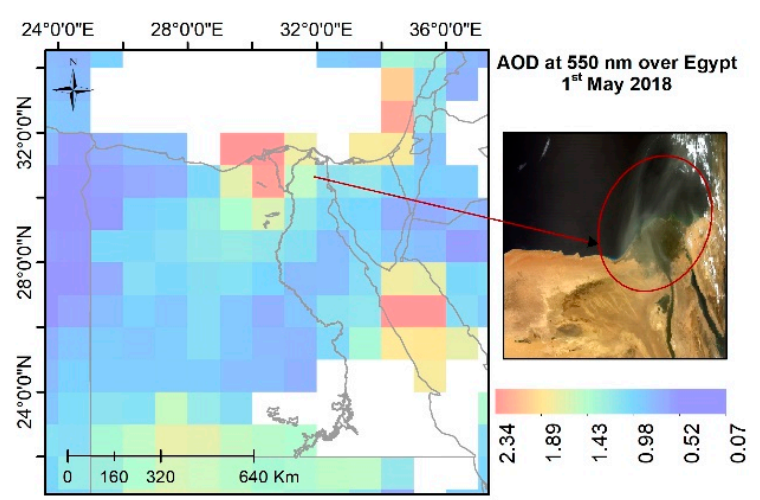

(a)

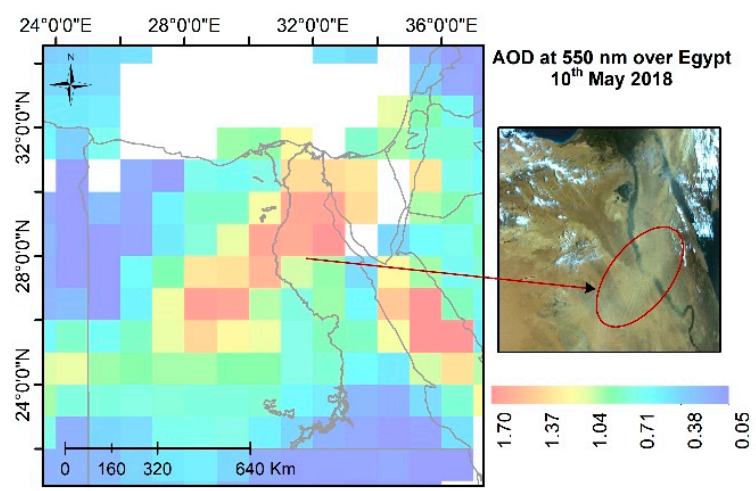

(b)

Figure 4. The observed dust storms on (a) 1 May 2018, and (b) 10 May 2018 over Egypt. * on the left, MODIS (level 3) AOD; on the right MODIS (level 1) radiance color image.
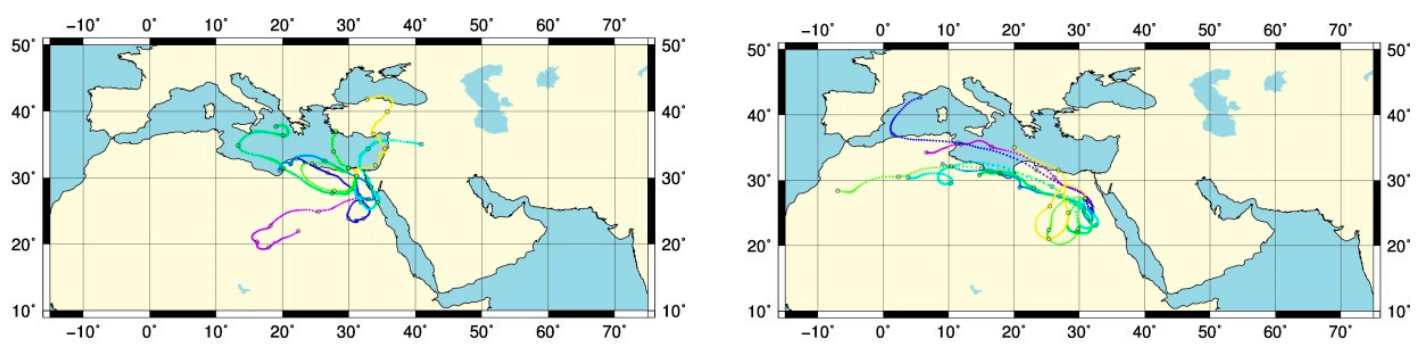

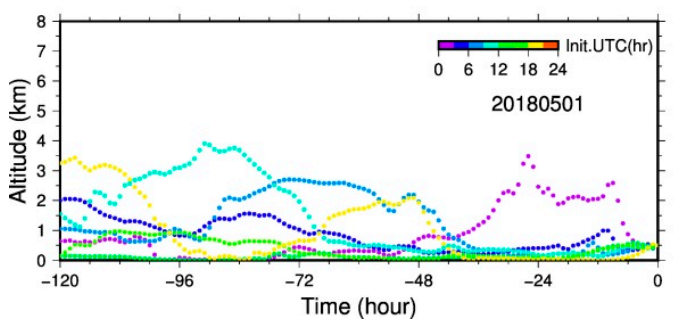

(a)

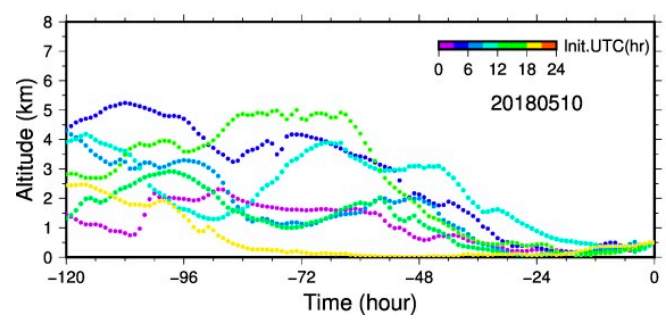

(b)

Figure 5. Five-day backward trajectory analyses initialized at (a) $30^{\circ} 15^{\prime} \mathrm{N} \& 31^{\circ} 10^{\prime} \mathrm{E}$ on 1 May 2018, (b) $27^{\circ} 14^{\prime} \mathrm{N} \& 30^{\circ} 58^{\prime}$ on 10 May 2018. The bottom panel shows the trajectories with time (0-120 h/backward) and altitude (0-500 m).

To understand the seasonal changes in aerosol loading and properties over Egypt, monthly averaged values of AOD are presented in Figure 6. The figure clearly shows the AOD fluctuations 
between seasons during the time of observation from 2012-2018. April and May (spring season) showed the highest AOD, followed by June, July, August (summer) and September (autumn), while the winter season (January, February and December) showed the lowest AOD. The spatial distribution of AOD over seasons covering the geographical boundary of Egypt from 2012 to 2018 (Figure 7) was explored using combined Dark Target and Deep Blue MODIS AOD data. These maps present the variations in AOD distribution with seasons. AOD loading in winter was very low, particularly over coastal areas: the maximum AOD value was 0.29, distributed over some parts of the western desert and Nile delta. AOD started to increase in spring and reached its maximum (0.42) over the Nile delta. The summer maximum AOD concentrated at the south and east regions with a value of 0.47 . In autumn, a slight decrease in AOD load was recorded with the highest value (0.36) observed in the Nile delta region. The results agree with the study of Shokr et al., [36] who revealed that a seasonal cycle peak was observed in spring and summer with values between 0.4 and 0.5 , and a minimum in winter with values less than 0.35 , with a similar distribution of aerosol loading concentrated in the western desert and Nile delta.

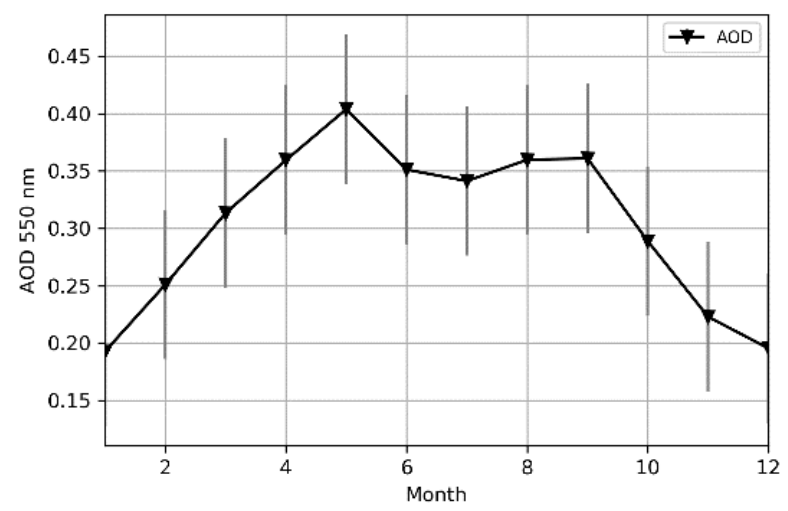

Figure 6. AOD climatology from MODIS Terra over Egypt for the period 2012-2018; the vertical line represents standard deviation.

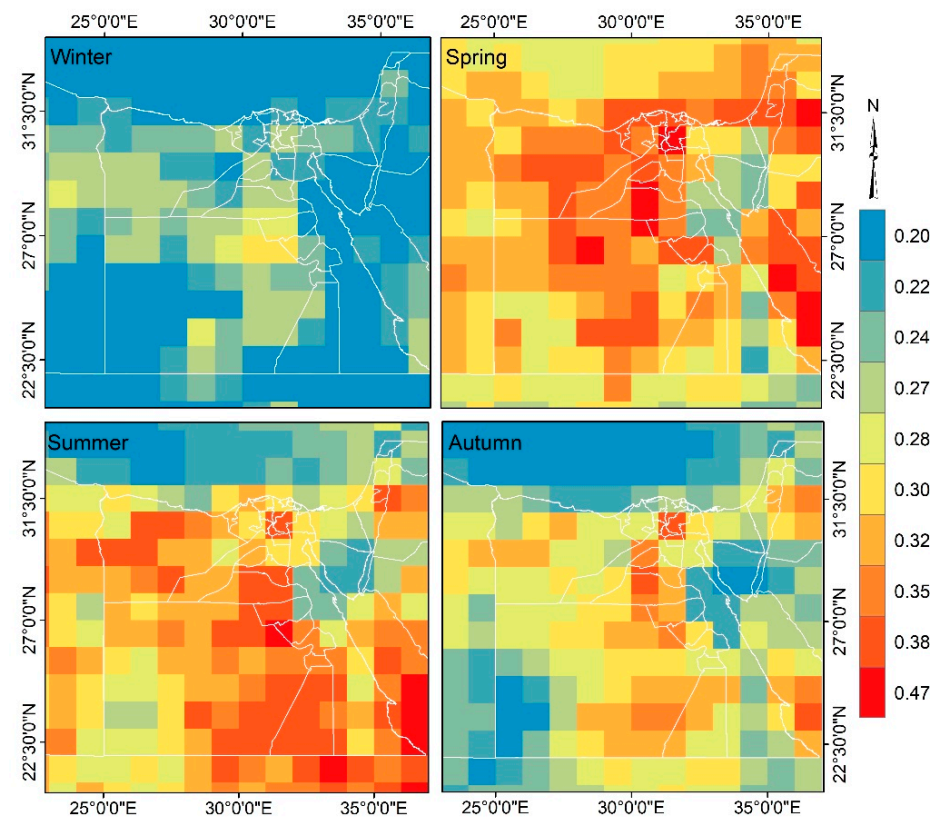

Figure 7. Seasonal variations of AOD over Egypt using level 3 combined Dark Target (DT) and Deep Blue (DB) MODIS Terra data at $550 \mathrm{~nm}$; data are averaged for winter (DJF), spring (MAM), summer (JJA), autumn (SON) during 2012-2018. 


\subsection{AERONET}

The analysis of AOD data from AERONET for Cairo (Figure 8) shows a temporal variation over the year comparable to MODIS AOD. The AOD curve is not consistent; it varies between months and shows a high AOD in April and May. Therefore, the climatology of AOD for the period 2012-2018 was investigated to understand the seasonal changes in aerosol loading (Figure 9a). In addition, the AE climatology was explored to distinguish the aerosol size according to each season (Figure 9b). It can be observed that spring has the highest AOD (about 0.4) in May, with the lowest AE, at less than 0.7. Additionally, autumn (September/October/November) and summer (June/July/August) showed slightly higher AOD values, with high AE values that exceeded 1 in autumn and 1.1 in summer. In contrast, winter (January/February) had the lowest AOD with high AE values.

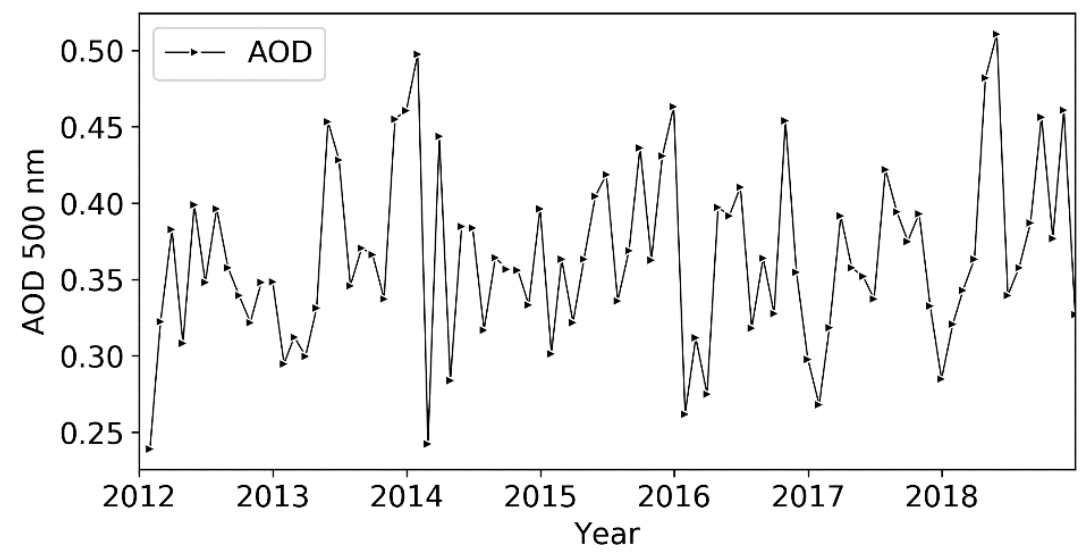

Figure 8. Monthly average AOD (500 nm) from AERONET at the "Cairo EMA-2" station for the period 2012 to 2018.

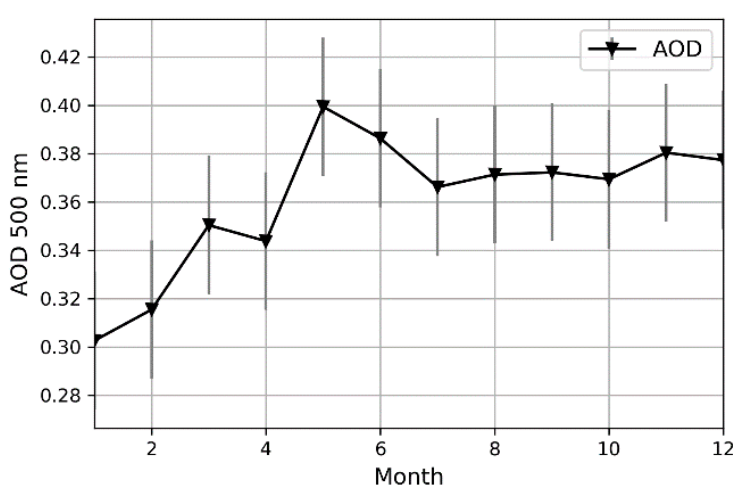

(a)

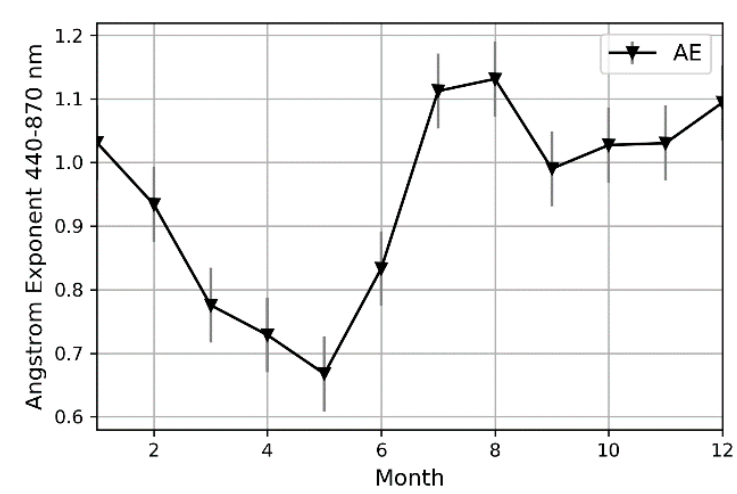

(b)

Figure 9. Time series of AERONET AOD for the period 2012-2018 from Cairo EMA-2 station, (a) AOD at $500 \mathrm{~nm}$, (b) Ångström exponent (AE) 440-870 nm.

The high Ångström exponent values in autumn indicate the presence of fine mode particles. Thus, the observed fires in October and November from MODIS fire data were used to examine this result. Fire data confirm the local human activities from farmers that contribute to the aerosols and AOD column over Egypt. There were 246 incident fires, the majority of which were in October (63\%), which is the main harvesting month for rice crops, and $37 \%$ were in November. Most of these fire incidents $(68 \%)$ occurred at night due to the local environmental regulations that penalize people for such fires. The confidence level of these fire spots is high, with 162 fire incidents having above $50 \%$ confidence (Figure 10). 


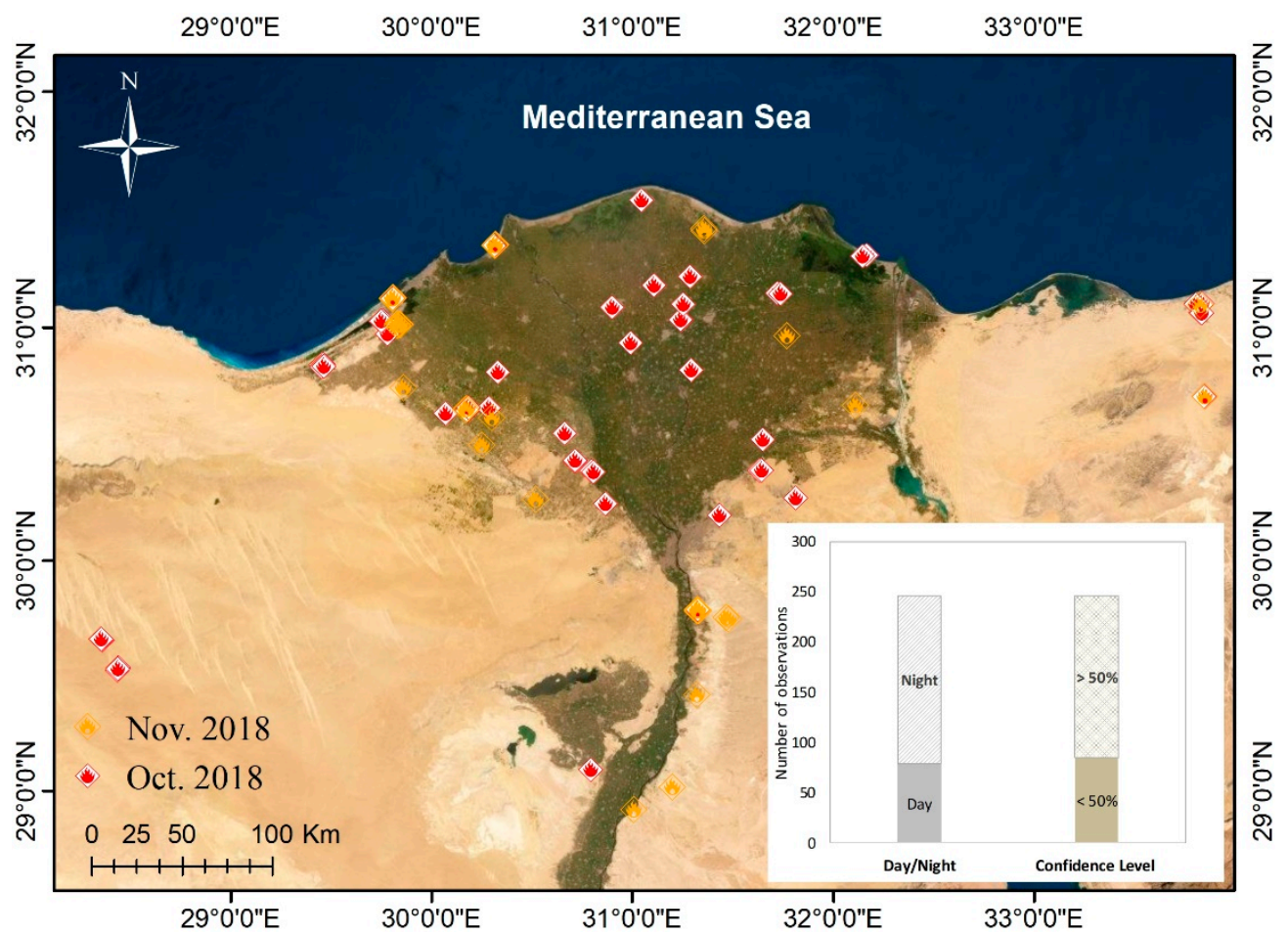

Figure 10. Observed fire spots over Egypt in Autumn (October and November 2018); the lower right plot presents the number of observed fires during the day and night and their confidence level.

\subsection{Validation}

The in-situ measurements of $\mathrm{PM}_{10}$ obtained from EEAA in 2016 were used to validate the AOD by MODIS. In addition, the record of some dust events observed by the EEAA early warning system was compared with the high AOD from MODIS. In 2016, 24 cases of dust storms were recorded in 47 days in the winter, spring and autumn months. According to this record, Figure 11 presents the monthly AOD derived from MODIS over Egypt in 2016, highlighting the observed high AOD peaks, which match well with the real dust events recorded at the same time. For instance, in April, there was a dust event from the 8th to 11th, and we can observe that AOD reached its peak on the 8th and 9th of the month. Furthermore, two dust events recorded on 9th-11th and on 20th November aligned with the two AOD peaks observed on the 10th and on 20th of the month. Table 3 presents the number of dust events observed through the EEAA and corresponding monthly average MODIS AOD and standard deviation. 

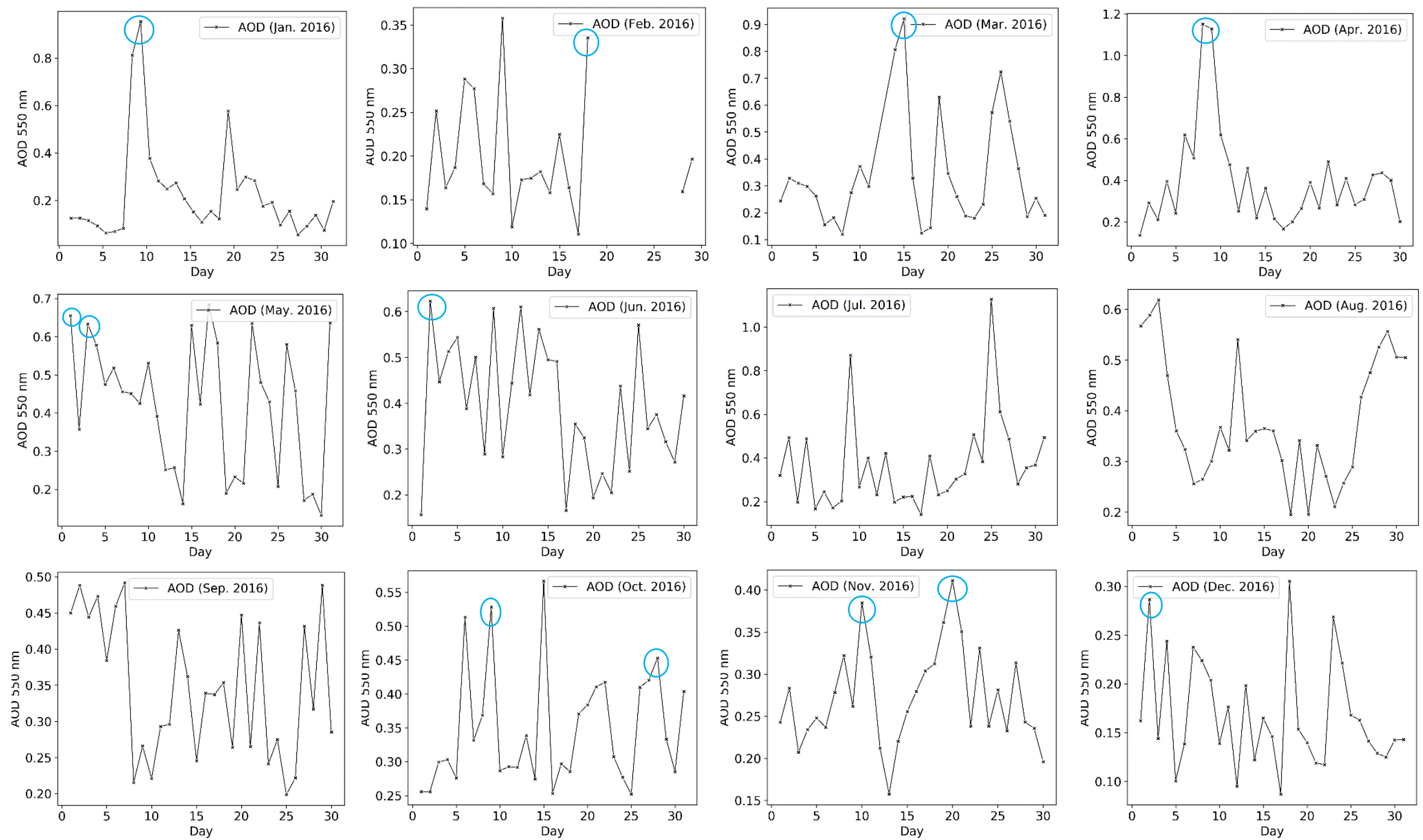

Figure 11. Monthly variations of MODIS AOD in 2016 over Egypt; blue circles highlight the dusty days obtained from EEAA monitoring networks that match AOD peaks. 
Table 3. Number of recorded dust events in 2016 from EEAA, with corresponding monthly mean MODIS AOD and standard deviation.

\begin{tabular}{|c|c|c|c|c|c|c|c|c|c|c|c|c|}
\hline Month & 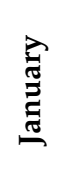 & 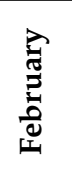 & 节 & 胥 & $\stackrel{\vec{J}}{\Sigma}$ & $\stackrel{\Xi}{\Xi}$ & $\underline{ }$ & 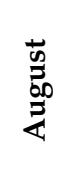 & 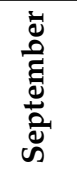 & 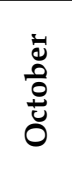 & 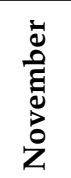 & 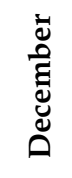 \\
\hline No. of dust events & 3 & 3 & 3 & 5 & 2 & 2 & - & - & - & 3 & 2 & 1 \\
\hline Duration/day & 8 & 6 & 4 & 8 & 2 & 2 & & & & 3 & 12 & 2 \\
\hline Mean & 0.22 & 0.12 & 0.34 & 0.39 & 0.42 & 0.39 & 0.37 & 0.38 & 0.35 & 0.35 & 0.27 & 0.17 \\
\hline Std. Dev. & 0.21 & 0.07 & 0.21 & 0.24 & 0.17 & 0.14 & 0.21 & 0.12 & 0.1 & 0.09 & 0.06 & 0.06 \\
\hline
\end{tabular}

In addition to validating MODIS data with AERONET, MODIS data were filtered for an area of $20 \mathrm{~km}^{2}$ around the "Cairo EMA-2" station for the same observation time. Then, a regression analysis [53] was performed on the daily mean measures of AOD from both instruments (Figure 12); the regression gives a correlation coefficient $(\mathrm{R})$ of about 0.73 .

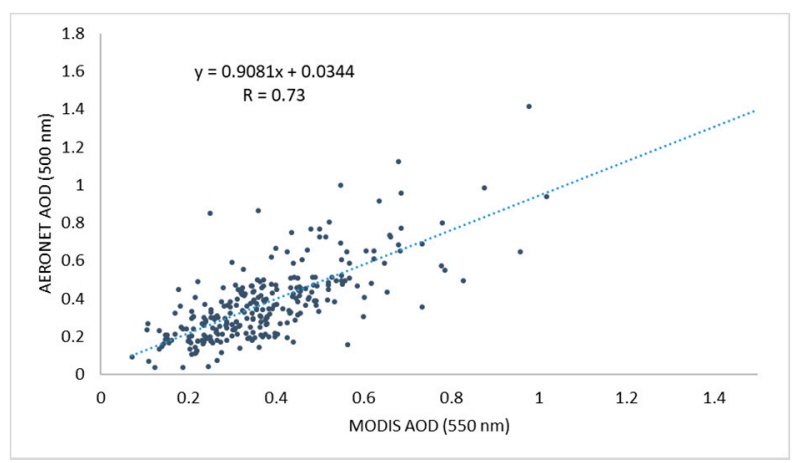

Figure 12. Regression analysis of AOD from MODIS at $550 \mathrm{~nm}$ with AOD from AERONET at $500 \mathrm{~nm}$ over Cairo. MODIS data were used for an area of $20 \mathrm{~km}^{2}$ around the "Cairo EMA-2" station during the period 2012-2018.

\section{Discussion}

Based on the temporal variations of aerosol optical data from MODIS and AERONET, fluctuations in monthly AOD are presented in Figures 2 and 8. For MODIS, March, May, August and September had the highest AOD, with the maximum value in May 2018. Consequently, a detailed analysis of AOD in 2018 was performed on a daily basis (Figure 3), which revealed that May had the maximum readings of all the days of the year. By examining the days of this month deeply using MODIS level 2 colored images, two dust storms were observed on the 1st and 10th of May 2018 (Figure 4). The distribution of level 3 AOD was matched spatially with both events, and the highest AOD values were recorded with the same pathway of the storm in the colored MODIS image. In order to keep track of the source of the high aerosol loading at this time, the trajectory analysis showed the five-day backward pathway of the air masses, as shown in Figure 5. The prevalent directions of the north (Mediterranean Sea) and west (Sahara Desert) influenced the aerosol loading through the long-range transport of air masses. Air masses from these directions carry dust particles from the Sahara region towards Egypt. This leads to an accumulation of coarse mode particles at this time of the year.

AOD climatology (Figure 6) and maps of seasonal variation (Figure 7) for the period 2012-2018 showed high AOD values recorded in spring, followed by summer and autumn. These seasons were strongly influenced by the regional climatic condition (e.g., wind velocity), which enhances the formation of dust storms and sea salt, and local micro-scale human activities. Spring has the highest $\mathrm{AOD}$; this may be due to the effect of dust storms originating from the western desert during this season, as mentioned previously in Figures 4 and 5. Furthermore, in summer, the absence of precipitation aside 
from the photochemical reactions in the atmosphere due to the high temperature increases aerosol accumulation. In addition, autumn has slightly higher AOD values owing to the effect of local biomass burning in the Delta region as a major micro-scale human activity. In contrast, winter (the wet season) had the lowest aerosol loading due to the occurrence of rain, which increased precipitation rates, washing the aerosol particles from the atmosphere and decreasing AOD levels. These findings were confirmed by the study presented in [41] which revealed that winter has a lower AOD content than other seasons, while summer has a slightly higher AOD due to the lack of precipitation. Papadimas [34] showed that precipitation in winter is a strong removal process for atmospheric AOD, while in summer, anthropogenic aerosols are one of the common causes of AOD.

It is therefore obvious that aerosols over northern Egypt and the Nile delta region have local and regional origins [54]. The seasonal aerosols may be either from natural sources-for example, dust particles transported from the western desert and maritime particles produced over the Mediterranean Sea in the case of strong winds-or anthropogenic aerosols, which are produced from industrial areas or from seasonal biomass burning as smoke particles. During other seasons, mainly spring, desert dust transport is a major contributor [42,55].

The Angström exponent is considered an indicator of the aerosol size distribution in the atmosphere. It is widely used to explain the correlation of wavelength with AOD, where it strongly depends on wavelength [19]. The investigation of AOD (500 nm) and AE (440-870) climatology (Figure 9) during the observation period revealed that the high AOD in spring coincides with low AE values $(<0.7)$, which demonstrates the presence of coarse-mode aerosols. An AE value $\leq 1$ indicates that the aerosol size distribution is mainly dominated by coarse particles of an effective radius usually $>0.5 \mu \mathrm{m}$ [4], which originates from desert dust outflows or maritime aerosols (particularly over coastal areas). This is attributed to the well-known intense dust storms over the Sahara Desert associated with the predominant south-western winds during this time, called "Khamasin wind" [37]. In summer (July, August) and autumn (September, October, November), AOD had slightly higher identical values associated with the highest $\mathrm{AE}$ in summer $(>1.1)$ and slightly higher values in autumn (1-1.1). The maximum AE observed in summer indicates the presence of fine particles originating from anthropogenic sources, where Egypt is exposed to long-range transport not only from the Saharan dust, but also from anthropogenic pollutants mainly from Europe. The concentrations of these transported anthropogenic aerosols are very high during the warm period of the year due to the absence of precipitation and the prevailing trade wind patterns in addition to photochemical activity in the atmosphere [55-58].

Furthermore, the high AE values in autumn were associated with smoke particles and anthropogenic aerosols, which are dominant during this period due to open fires as a result of burning agricultural waste (rice straws) in the Nile delta. Figure 10 presents the fire spots over North Egypt in October and November-the season of burning agricultural waste. These incident fires coupled with the local emission and long-range transport of pollutants during autumn resulted in a local phenomenon known as "black cloud" over Cairo and the delta $[33,37,41]$. In contrast, the low AOD in winter (January, February) is associated with slightly higher AE (0.9-1) values, which indicate the abundance of fine-mode particles. An AE value $\geq 1$ usually indicates a particle size distribution dominated by fine-mode aerosols of an effective radius $<0.5 \mu \mathrm{m}$, usually associated with urban pollution and biomass burning [59]. In order to validate the results, actual in-situ measurements of $\mathrm{PM}_{10}$ with a record of the dust events in 2016 (obtained from ground monitoring stations) were compared with MODIS data (Figure 11, Table 3). The high AOD values from MODIS PM 10 were comparable to some observed dusty days in January, February, March, April, May, June, October, November and December. In addition, a regression analysis of MODIS and AERONET aerosol data gave a correlation coefficient $(\mathrm{R})$ of about 0.73 (Figure 12). 


\section{Conclusions}

In conclusion, this research intensively explored all related sources of information to characterize and provide an understanding of the aerosol optical characteristics and pattern over Egypt in the period 2012-2018 on daily, monthly and seasonal bases. This is the first time such a comprehensive analysis has been made to create a complete and clear picture of the aerosol climatology over Egypt. Remotely sensed data of MODIS and AERONET were used to derive AOD variations and validated using in-situ measurements of $\mathrm{PM}_{10}$. The comprehensive time series climatology analysis of AOD (500 and $550 \mathrm{~nm}$ ) and AE (440-870 nm) provided the seasonal anomalies over Egypt, particularly in autumn and spring seasons; however, the drivers are different. The spring is commonly problematic, with prevalent coarse mode particles in the months of April and May, the regional driver of which is the Khamasin wind that carries dust storms from the Sahara Desert to Egypt in its pathways to Europe or/and west Asia. This is confirmed by the inverse correlation of the AE. Autumn is concentrated with fine mode anthropogenic particles as a result of local human activities of burning crop stews in the Nile delta, which is also confirmed by the correlation with AE. Of the 246 fires recorded in 2018 during the months of harvesting rice crops, $68 \%$ were at night, which could be explained by the attempt to avoid the environmental regulations which penalize farmers for such fires. It was also found that the confidence level of these fire spots was high; 162 fire incidents had a confidence above $50 \%$. All of these fires support the high AOD and low AE in spring. In summer, the anthropogenic aerosols are of great interest due to the photochemical reactions in atmosphere. $\mathrm{PM}_{10}$ records of dust storms are correlated with the extremely high MODIS AOD values that support the regional drivers of AOD in summer. Further, the regression analysis of MODIS and AERONET gave a strong correlation coefficient $(\mathrm{R}=0.73)$, creating a complete picture of the aerosol distribution over Egypt. Therefore, we can conclude that the seasonal aerosols over Egypt may be either from natural causes, including dust particles transported from the Western desert and maritime particles produced over the Mediterranean Sea-particularly in coastal areas in the case of high wind speeds-or anthropogenic aerosols from transportation or industrial areas and smoke particles from seasonal biomass burning.

Author Contributions: Conceptualization, I.A.E.-M.; N.Z.; E.M.A. and H.I.; methodology, I.A.E.-M.; N.Z.; software, N.Z.; H.I.; validation I.A.M.; N.Z. and H.I.; formal analysis, I.A.M. and N.Z.; investigation, I.A.E.-M., N.Z. and E.M.A.; resources, I.A.M.; E.M.A.; H.I.; data curation, I.A.M. and N.Z.; writing-original draft preparation N.Z.; E.M.A. writing-review and editing, I.A.E.-M.; N.Z.; E.M.A. and A.I.A.; visualization, I.A.E.-M.; N.Z. and A.I.A. All authors have read and agreed to the published version of the manuscript.

Funding: There is no external fund for this research.

Acknowledgments: The authors would like to thank and acknowledge the use of MODIS data products for

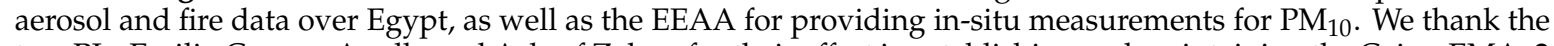
two PIs, Emilio Cuevas-Agullo and Ashraf Zakey, for their effort in establishing and maintaining the Cairo_EMA_2 AERONET site.

Conflicts of Interest: The authors declare no conflict of interest.

\section{References}

1. Twomey, S. Atmospheric Aerosols; Elsevier Scientific Publishing, Co.: New York, NY, USA, 1977.

2. Andrews, E.; Ogren, J.A.; Bonasoni, P.; Marinoni, A.; Cuevas, E.; Rodríguez, S.; Sun, J.Y.; Jaffe, D.A.; Fischer, E.V.; Baltensperger, U.; et al. Climatology of aerosol radiative properties in the free troposphere. Atm. Res. 2011, 102, 365-393. [CrossRef]

3. Appel, B.R.; Tokiwa, Y.; Hsu, J.; Kothny, E.L.; Hahn, E. Visibility as related to atmospheric aerosol constituents. Atm. Environ. (1967) 1985, 19, 1525-1534. [CrossRef]

4. Soni, K.; Singh, S.; Bano, T.; Tanwar, R.S.; Nath, S. Wavelength Dependence of the Aerosol Angstrom Exponent and Its Implications Over Delhi, India. Aerosol Sci. Tech. 2011, 45, 1488-1498. [CrossRef]

5. Kaskaoutis, D.G.; Kambezidis, H.D.; Hatzianastassiou, N.; Kosmopoulos, P.; Badarinath, K.V.S. Aerosol Climatology: On the Discrimina- tion of the Aerosol Types Over Four AERONET Sites. Atmos. Chem. Phys. Discuss 2007, 7, 6357-6411. [CrossRef] 
6. Varga, G. Changing nature of Saharan dust deposition in the Carpathian Basin (Central Europe): 40 years of identified North African dust events (1979-2018). Environ. Inter. 2020, 139, 105712. [CrossRef] [PubMed]

7. Engelstaedter, S.; Tegen, I.; Washington, R. North African dust emissions and transport. Earth-Sci. Rev. 2006, 79, 73-100. [CrossRef]

8. Marinou, E.; Amiridis, V.; Binietoglou, I.; Tsikerdekis, A.; Solomos, S.; Proestakis, E.; Konsta, D.; Papagiannopoulos, N.; Tsekeri, A.; Vlastou, G.; et al. Three-dimensional evolution of Saharan dust transport towards Europe based on a 9-year EARLINET-optimized CALIPSO dataset. Atmos. Chem. Phys. 2017, 17, 5893-5919. [CrossRef]

9. Ginoux, P.; Chin, M.; Tegen, I.; Prospero, J.; Holben, B.; Dubovik, O.; Lin, S.-J. Sources and distributions of dust aerosols simulated with the GOCART model. J. Geophys. Res. Space Phys. 2001, 106, 20255-20273. [CrossRef]

10. Miller, R.L.; Tegen, I.; Perlwitz, J. Surface radiative forcing by soil dust aerosols and the hydrologic cycle. J. Geophys. Res. Space Phys. 2004, 109, 203. [CrossRef]

11. Goudie, A.S.; Middleton, N.J. Desert Dust in the Global System; Springer: Berlin/Heidelberg, Germany, 2006; p. 287.

12. Varga, G.; Kovács, J.; Újvári, G. Analysis of Saharan dust intrusions into the Carpathian Basin (Central Europe) over the period of 1979-2011. Glob. Plan. Chan. 2013, 100, 333-342. [CrossRef]

13. Rodríguez, S.; Querol, X.; Alastuey, A.; Kallos, G.; Kakaliagou, O. Saharan dust contributions to PM10 and TSP levels in Southern and Eastern Spain. Atm. Environ. 2001, 35, 2433-2447. [CrossRef]

14. Matassoni, L.; Pratesi, G.; Centioli, D.; Cadoni, F.; Lucarelli, F.; Nava, S.; Malesani, P. Saharan dust contribution to PM10, PM2.5 and PM1in urban and suburban areas of Rome: A comparison between single-particle SEM-EDS analysis and whole-sample PIXE analysis. J. Environ. Monit. 2011, 13, 732-742. [CrossRef] [PubMed]

15. Gerasopoulos, E.; Kouvarakis, G.; Babasakalis, P.; Vrekoussis, M.; Putaud, J.P.; Mihalopoulos, N. Origin and variability of particulate matter (PM10) mass concentrations over the Eastern Mediterranean. Atm. Environ. 2006, 40, 4679-4690. [CrossRef]

16. Wheeler, D.A. The meteorological background to the fall of Saharan dust, November 1984. Meteo. Mag. 1986, 115, 1-9.

17. Klein, H.; Nickovic, S.; Haunold, W.; Bundke, U.; Nillius, B.; Ebert, M.; Weinbruch, S.; Schuetz, L.; Levin, Z.; Barrie, L.A.; et al. Saharan dust and ice nuclei over Central Europe. Atmo. Chem. Phys. 2010, 10, 10211-10221. [CrossRef]

18. Holben, B.N.; Eck, T.F.; Slutsker, I.; Tanré, D.; Buis, J.P.; Setzer, A.; Vermote, E.; Reagan, J.A.; Kaufman, Y.J.; Nakajima, T.; et al. AERONET-A federated instrument network and data archive for aerosol characterization. Remote Sens. Environ. 1998, 66, 1-16. [CrossRef]

19. Lee, K.H.; Li, Z.; Kim, Y.J.; Kokhanovsky, A. Atmospheric Aerosol Monitoring from Satellite Observations: A History of Three Decades. In Atmospheric and Biological Environmental Monitoring; Kim, Y.J., Platt, U., Gu, M.B., Iwahashi, H., Eds.; Springer: Dordrecht, The Netherlands, 2009; pp. 13-37. [CrossRef]

20. Remer, L.A.; Kleidman, R.G.; Levy, R.C.; Kaufman, Y.J.; Tanre, D.; Mattoo, S.; Martins, J.V.; Ichoku, C.; Koren, I.; Yu, H.; et al. Global aerosol climatology from the MODIS satellite sensors. J. Geophys. Res. 2008, 113, D14S07. [CrossRef]

21. Filonchyk, M.; Yan, H.; Zhang, Z.; Yang, S.; Li, W.; Li, Y. Combined use of satellite and surface observations to study aerosol optical depth in different regions of China. Nat. Sci. Rep. 2019, 9, 6174. [CrossRef] [PubMed]

22. Mehta, M. A study of aerosol optical depth variations over the Indian region using thirteen years (2001e2013) of MODIS and MISR Level 3 data. Atm. Environ. 2015, 109, 161-170. [CrossRef]

23. Verma, S.; Prakash, D.; Soni, M.; Ram, K. Atmospheric Aerosols Monitoring: Ground and Satellite-Based Instruments. Aerosols Monitoring: Ground and Satellite-Based Instruments. In Advances in Environmental Monitoring and Assessment; Sarvajayakesavalu, S., Ed.; IntechOpen: London, UK, 2019; pp. 67-80.

24. Levy, R.C.; Remer, L.A.; Dubovik, O. Global aerosol optical properties and application to Moderate Resolution Imaging Spectroradiometer aerosol retrieval over land. J. Geophys. Res. Space Phys. 2007, 112. [CrossRef]

25. Levy, R.C.; Remer, L.A.; Mattoo, S.; Vermote, E.F.; Kaufman, Y.J. Second-generation operational algorithm: Retrieval of aerosol properties over land from inversion of Moderate Resolution Imaging Spectroradiometer spectral reflectance. J. Geophys. Res. Space Phys. 2007, 112, D13. [CrossRef] 
26. Hsu, N.; Tsay, S.-C.; King, M.D.; Herman, J.R. Aerosol Properties Over Bright-Reflecting Source Regions. IEEE Trans. Geosci. Remote. Sens. 2004, 42, 557-569. [CrossRef]

27. Hsu, N.; Tsay, S.-C.; King, M.D.; Herman, J.R. Deep Blue Retrievals of Asian Aerosol Properties During ACE-Asia. IEEE Trans. Geosci. Remote. Sens. 2006, 44, 3180-3195. [CrossRef]

28. Hsu, N.C.; Jeong, M.-J.; Bettenhausen, C.; Sayer, A.M.; Hansell, R.; Seftor, C.S.; Huang, J.; Tsay, S.-C. Enhanced Deep Blue aerosol retrieval algorithm: The second generation. J. Geophys. Res. Atmos. 2013, 118, 9296-9315. [CrossRef]

29. Rezaei, M.; Farajzadeh, M.; Mielonen, T.; Ghavidel, Y. Analysis of spatio-temporal dust aerosol frequency over Iran based on satellite data. Atmos. Pollut. Res. 2019, 10, 508-519. [CrossRef]

30. Kaskaoutis, D.; Sifakis, N.; Retalis, A.; Kambezidis, H.D. Aerosol Monitoring over Athens Using Satellite and Ground-Based Measurements. Adv. Meteorol. 2010, 2010, 1-12. [CrossRef]

31. Su, B.; Li, H.; Zhang, M.; Bilal, M.; Wang, M.; Atique, L.; Zhang, Z.; Zhang, C.; Han, G.; Qiu, Z.; et al. Optical and Physical Characteristics of Aerosol Vertical Layers over Northeastern China. Atmosphere 2020, 11, 501. [CrossRef]

32. Shaw, N.; Gorai, A.K. Study of aerosol optical depth using satellite data (MODIS Aqua) over Indian Territory and its relation to particulate matter concentration. Environ. Dev. Sustain. 2018, 22, 265-279. [CrossRef]

33. Li, W.; Ali, E.; El-Magd, I.A.; Mourad, M.M.; El-Askary, H.M. Studying the Impact on Urban Health over the Greater Delta Region in Egypt Due to Aerosol Variability Using Optical Characteristics from Satellite Observations and Ground-Based AERONET Measurements. Remote. Sens. 2019, 11, 1998. [CrossRef]

34. Papadimas, C.D.; Hatzianastassiou, N.; Mihalopoulos, N.; Querol, X.; Vardavas, I. Spatial and temporal variability in aerosol properties over the Mediterranean basin based on 6- year (2000-2006) MODIS data. J. Geophys. Res. 2008, 113, D11205. [CrossRef]

35. El-Metwally, M.; Alfaro, S.; Wahab, M.M.A.; Favez, O.; Mohamed, Z.; Chatenet, B. Aerosol properties and associated radiative effects over Cairo (Egypt). Atmos. Res. 2011, 99, 263-276. [CrossRef]

36. Shokr, M.; El-Tahan, M.; Ibrahim, A.; Steiner, A.; Gad, N. Long-Term, High-Resolution Survey of Atmospheric Aerosols over Egypt with NASA's MODIS Data. Remote Sens. 2017, 9, 1027. [CrossRef]

37. El-Askary, H.; Prasad, A.K.; El-Raey, M.; Kallos, G.; Kafatos, M. Analyzing Black Cloud Dynamics over Cairo, Nile Delta Region and Alexandria using Aerosols and Water Vapor Data. In Air Quality-Models and Applications; IntechOpen: London, UK, 2011; pp. 211-232. [CrossRef]

38. EL-ASKARY, H. Air pollution impact on aerosol variability over mega cities using remote sensing technology: Case study, Cairo. Eg. J. Rem. Sens. Spa. Sci. 2006, 9, 31-40.

39. El-Magd, I.A.; Ismail, A.; Zanaty, N. Spatial Variability of Urban Heat Islands in Cairo City, Egypt using Time Series of Landsat Satellite Images. Int. J. Adv. Remote Sens. GIS 2016, 5, 1618-1638. [CrossRef]

40. Zakey, A.S.; Abdel-Wahab, M.M.; Pettersson, J.B.C.; Gatari, M.J.; Hallquist, M. Seasonal and spatial variation of atmospheric particulate matter in a developing megacity, the Greater Cairo, Egypt. Atmósfera 2008, 21, 171189.

41. Marey, H.S.; Gille, J.C.; El-Askary, H.M.; Shalaby, E.A.; El-Raey, M.E.; El-Askary, H.M. Aerosol climatology over Nile Delta based on MODIS, MISR and OMI satellite data. Atmos. Chem. Phys. Discuss. 2011, 11, 10637-10648. [CrossRef]

42. Prasad, A.; El-Askary, H.M.; Kafatos, M. Implications of high altitude desert dust transport from Western Sahara to Nile Delta during biomass burning season. Environ. Pollut. 2010, 158, 3385-3391. [CrossRef]

43. Central Agency for Public Mobilization and Statistics (CAPMAS). Egypt in Figures-Population. Available online: https://www.capmas.gov.eg/Pages/StaticPages.aspx?page_id=5035 (accessed on 10 March 2020).

44. World health statistics 2017: Monitoring health for the SDGs, Sustainable Development Goals. Available online: https:/www.who.int/gho/publications/world_health_statistics/2017/en/WHO (accessed on 21 September 2019).

45. World health statistics 2018: Monitoring health for the SDGs, Sustainable Development Goals. Available online: https://www.who.int/gho/publications/world_health_statistics/2018/en/WHO (accessed on 21 September 2019).

46. IRIN (Integrated Regional Information Network) online report. 2008. Available online: https://www. thenewhumanitarian.org/news/2008/10/09/efforts-fight-\%E2\%80\%9Cblack-cloud\%E2\%80\%9D-cairo (accessed on 22 March 2020).

47. NASA MODIS. Available online: https://modis.gsfc.nasa.gov/data/ (accessed on 20 May 2019). 
48. Levy, R.C.; Mattoo, S.; Munchak, L.A.; Remer, L.A.; Sayer, A.M.; Patadia, F.; Hsu, N.C. The Collection 6 MODIS aerosol products over land and ocean. Atmos. Meas. Tech. 2013, 6, 2989-3034. [CrossRef]

49. Fire Information for Resource Management System (FIRMS). Available online: https://firms.modaps.eosdis. nasa.gov/active_fire/\#firms-shapefile (accessed on 15 March 2020).

50. Kolhe, A.R.; Pawar, G.V.; Varpe, S.R.; Kumar, P.P.; Devara, P.C.S.; Aher, G.R. Multi-Year Analysis of Aerosol Properties Retrieved from the Ångström Parameters for Different Spectral Ranges over Pune. Aerosol. Air Qual. Res. 2017, 16, 3266-3280. [CrossRef]

51. Vitali, L.; Righini, G.; Piersanti, A.; Cremona, G.; Pace, G.; Ciancarella, L. M-TraCE: A new tool for high-resolution computation and statistical elaboration of backward trajectories on the Italian domain. Theor. Appl. Clim. 2016, 129, 629-643. [CrossRef]

52. Zeng, J.; Matsunaga, T.; Mukai, H. METEX_A flexible tool for air trajectory calculation汸. Environ. Model. Softw. 2010, 25, 607-608. [CrossRef]

53. Tian, X.; Gao, Z. Validation and Accuracy Assessment of MODIS C6.1 Aerosol Products over the Heavy Aerosol Loading Area. Atmosphere 2019, 10, 548. [CrossRef]

54. Barnaba, F.; Gobbi, G.P. Aerosol seasonal variability over the Mediterranean region and relative impact of maritime, continental and Saharan dust particles over the basin from MODIS data in the year 2001. Atmos. Chem. Phys. Discuss. 2004, 4, 2367-2391. [CrossRef]

55. Kallos, G.; Astitha, M.; Katsafados, P.; Spyrou, C.; Spyrou, C. Long-Range Transport of Anthropogenically and Naturally Produced Particulate Matter in the Mediterranean and North Atlantic: Current State of Knowledge. J. Appl. Meteorol. Clim. 2007, 46, 1230-1251. [CrossRef]

56. Luria, M.; Peleg, M.; Sharf, G.; Tov-Alper, D.S.; Spitz, N.; Ben Ami, Y.; Gawii, Z.; Lifschitz, B.; Yitzchaki, A.; Seter, I. Atmospheric sulfur over the east Mediterranean region. J. Geophys. Res. Space Phys. 1996, 101, 25917-25930. [CrossRef]

57. Millan, M.M.; Salvador, R.; Mantilla, E.; Kallos, G. Photo oxidant dynamics in the Mediterranean basin in summer: Results from European research projects. J. Geophys. Res. 1997, 102, 8811-8823. [CrossRef]

58. Kallos, G.; Kotroni, V.; Lagouvardos, K.; Papadopoulos, A. On the Long-Range Transport of Air Pollutants from Europe to Africa. Geophys. Res. Lett. 1998, 25, 619-622. [CrossRef]

59. Eck, T.F.; Holben, B.N.; Reid, J.S.; Dubovik, O.; Smirnov, A.O.; Neill, N.T.; Slutsker, I.; Kinne, S. Wavelength Dependence of the Optical Dept of Bio Mass Burning, Urban, and Desert Dust Aerosols. J. Geophys. Res. 1999, 104, 31333-31349. [CrossRef] 